\title{
Pineal Parenchymal Tumor of Intermediate Differentiation: A Brief Report
}

\author{
Halil Kıyıcı ${ }^{1}$, Burcu Sanal ${ }^{1}$
}

'Selcuk University, Selcuklu Faculty of Medicine, Pathology Department

Eur J Basic Med Sci 2012;2(1):30-33

Received: 08.12.2011

Accepted: 09.03.2012

Correspondence (Yazışma Adresi): Dr. Halil Kiyıcl

Selçuk University, Selçuklu Faculty of Medicine, Pathology Department KONYA / TURKEY

Phone: 05332247208

E-mail: halilkiyici@hotmail.com

\begin{abstract}
The 2007 WHO classification of tumors of the central nervous system identified "pineal parenchymal tumor of intermediate differentiation" (PPTID) as a new pineal parenchymal neoplasm, located between pineocytoma and pineoblastoma as grade II or III [1]. Because of the small number of reported cases, the classification of pineal parenchymal tumors (PPT) is still a matter of controversy. We report a case of PPTID. A 23 years old female patient was admitted to hospital with a complaint of headache. A mass, $3.5 \mathrm{~cm}$ in diameter was found at the pineal region. Following operation, histopathological examination of the surgical specimen revealed a highly cellular tumor, with diffuse pattern and low mitotic activity (1/10HPF). There was no evidence of necrosis or pineocytomatous rosettes. Immunhistochemical examination showed strong and diffuse staining for synaptophysin. There was no expression of GFAP and chromogranin A. Ki-67 proliferation index was 7\%. An accurate grading is essential for these rare tumor, because optimal therapeutic management and prognosis depend on the histopathological grading. Significance of intraoperative evaluation for pineal tumors is still questionable. As a conclusion, it is preferable to use different terminologies for grade II and grade III PPTID.
\end{abstract}

Key words: Pineal, parenchymal, tumor, intermediate differentiation, grading 


\section{Intermedier Diferansiasyonlu Pineal Parenkimal Tümör}

\section{ÖZET}

Santral sinir sistemi tümörlerinin 2007 WHO sinıflandırmasında yeni bir pineal parenkimal tümör olarak intermedier diferansiasyonlu pineal parenkimal tümör de (PPTID) bulunmaktadır. PPTID, diferansiyasyon açısından pineositom ile pineoblastom arasında yerleșen, evre II ya da III olabilen bir tümordür. Az sayıda yayınlanmıș olgulardan dolayı pineal parenkimal tümörlerin sınıflandırması hala tartışma konusudur. Bu olgu sunumunda bir PPTID incelenmiștir. Olgu, baș ağrısı șikayeti ile hastaneye başvurmuștur. Incelemeler sonrasında pineal bölgede $3.5 \mathrm{~cm}$ çaplı tümör tespit edilmiștir. Operasyonu takiben yapılan histopatolojik incelemede, az sayıda mitoz içeren (1/10BB), difüz paternde selüler tümör görüldü. Nekroz veya pineositomatöz rozet izlenmedi. Immünhistokimyasal incelemede, sinaptofizin difuz ve yoğun boyanma gösterirken, GFAP ve kromogranin ekspresyonu yoktu. Ki-67 proliferasyon indeksi \%7'ydi. Bu nadir görülen tümörde doğru evreleme cok önemlidir. Çünkü optimal tedavi ve prognoz, histopatolojik evrelemeye bağlıdır. Pineal tümörlerde intraoperatif konsültasyonun değeri hala tartışmalıdır. Sonuç olarak her evreleme için farklı bir terminoloji kullanılması tercih edilebilir.

Anahtar Kelimeler: Pineal parenkimal tümör, intermedier diferansiasyon, evreleme

\section{INTRODUCTION}

Pineal parenchymal tumors (PPTs) represent about $30 \%$ of pineal region neoplasms. PPTs are rare tumors, accounting for less than $0.1 \%$ of all brain tumors. They are subdivided into pineocytoma (PC), pineoblastoma (PB) and PPT of intermediate differentiation (PPTID) $(1,2,3)$. Of pineal parenchymal tumors, pineocytomas and pineoblastomas represent approximately 45\% each, with pineal parenchymal tumors of intermediate differentiation (PPTID) accounting for the remaining $10 \%$ (4). Due to the small number of reported cases, the classification of parenchymal tumors (PPTs), especially PPTIDs, remains controversial $(2,5)$. Little is known about their clinical behaviour, and optimal management of these tumors has not yet been defined $(6,7)$.

PPTID was recognized in the 2007 WHO classification as a new pineal parenchymal neoplasm, intermediate in malignancy (WHO grade II and III) between pineocytoma (grade I) and pineoblastoma (grade IV) (8). This category was first introduced by Schild et al, in 1993. It occurs at all ages, including childhood to adult life, with a pick incidence in early adults (1).
Histopathologically, PPTID is located between pineocytoma and pineoblastoma. PPTIDs are composed of diffuse sheets or large lobules of monomorphic, uniform, round cells and characterized by moderate to high cellularity, mild to moderate nuclear atypia and low to moderate mitotic activity. Occasional giant cells, Homer Wright rosettes or ganglion cells may infrequently be seen (1). Neuronal and/or neuroendocrine differentiation is variable. Despite marked cellularity, neither endothelial proliferation nor necrosis is found. In all tumors numerous vessels were seen. Compared to pineocytomas, these tumors have a higher potential for focal invasion, recurrence and leptomeningeal dissemination.

In PPTIDs, the expression of neuronal markers is variable. Staining for synaptophysin is mainly diffuse, cytoplasmic and variable in intensity. Neurofilament protein (NFP) expression is variable. Chromogranin A can be especially expressed in PPTIDs with a pseudolobulated architecture. GFAP and S-100 protein staining is only positive in reactive interstitial astrocytes. Ki 67 proliferation index is between $3-10 \%(9)$.

\section{CASE REPORT}

A 23-year-old woman presented with increasing headache for a long time. On neurological examination, she had a paralysis of upward gaze but she exhibited no other neurological deficits. Contrasted cranial magnetic resonance imaging (MRI) revealed a mass with cystic and solid components, had a diameter of $3.5 \mathrm{~cm}$,

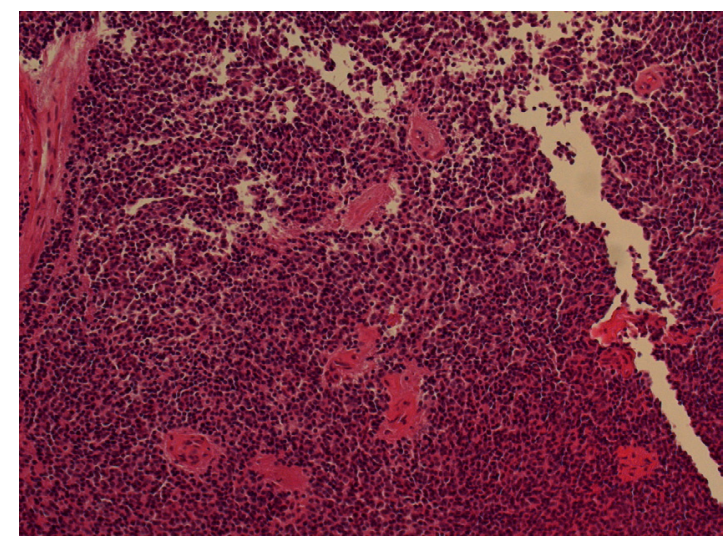

Figure 1. Grade II tumor with prominent vascular proliferation, but without necrosis or rosette formation. $H \& E$ staining, x200 magnification. 


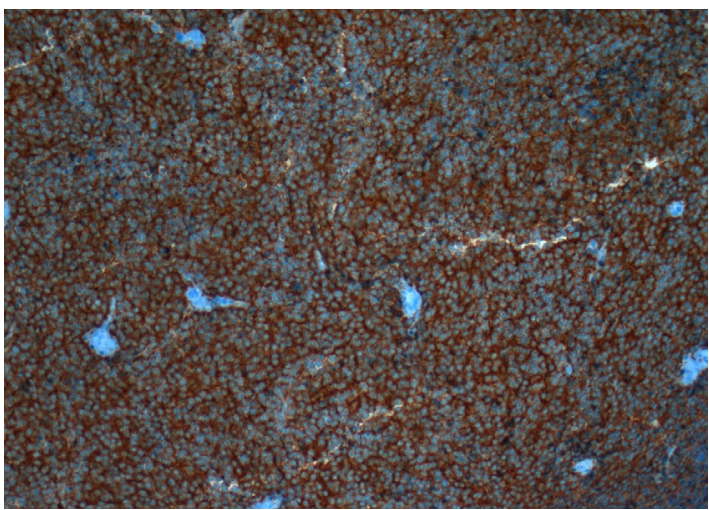

Figure 2. Strong and diffuse immunhistochemical staining for synaptophysin; x100 magnification.

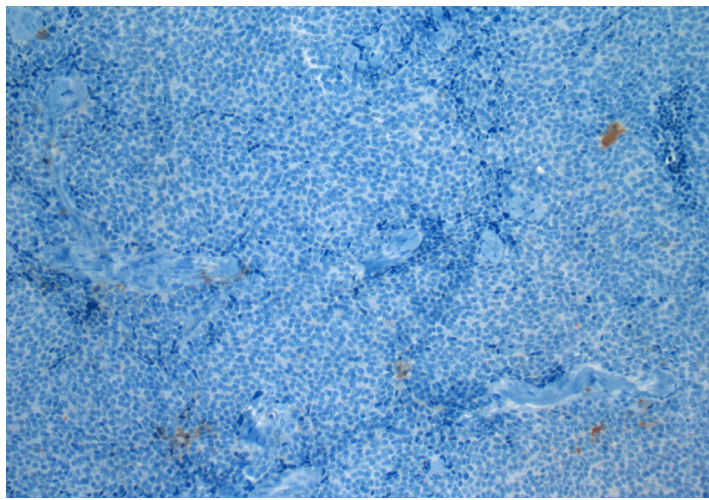

Figure 4. No expression of chromogranin A x100 magnification.

and is located at pineal area. Solid component of tumor showed well contrast enhancement. Lateral ventricle and third ventricle were exceedingly dilated. Because of the localization of the tumor, the cerebral aqueduct was compressed, resulting obstructive hydrocephalus. Cerebral magnetic resonance venography showed hypoplastic left temporal sinus. Laboratory findings of hormones (such as growth hormone, prolactine, cortisol, TSH, freeT3-T4, LH, FSH), tumor markers (Ca-125, AFP, Ca 19-9, Ca 15-3, CEA, Ca 72-4) and other biochemical analyses were within normal limits.

Then, the patient underwent the surgery with intraoperative consultation. Frozen section findings were consistent with neoplastic proliferation without any mitotic activity. Remaining specimen of frozen section material was fixed in $4 \%$ formaline solution and embedded in paraffin, then cut into $4 \square \mathrm{m}$ sections.

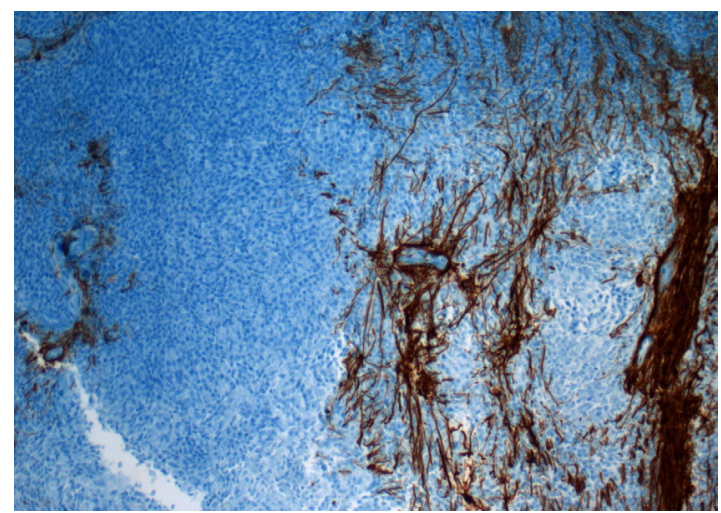

Figure 3. No expression of GFAP except glial fibrillary component; $x 100$ magnification.

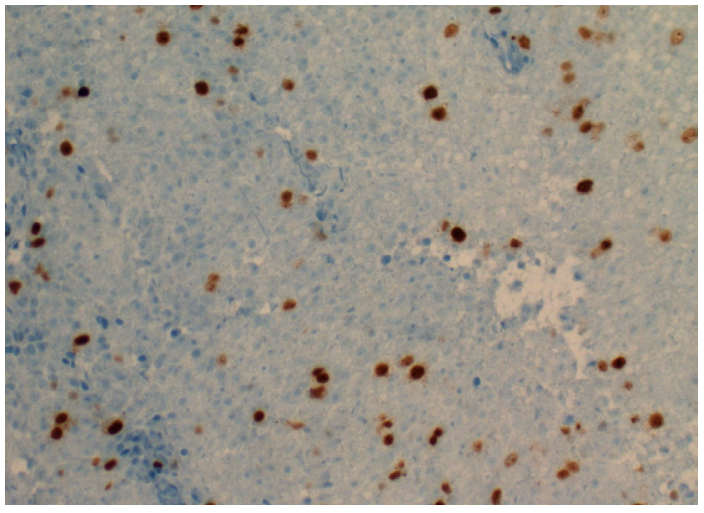

Figure 5. Approximately $7 \%$ of tumor cells show positive nuclear staining for Ki-67; x100 magnification.

Routine staining was performed using haematoxylineosin. There was high cellularity with mild nuclear pleomorphism. Mitotic activity, necrosis and formation of rosettes were not seen. Ki-67 labeling index was $6 \%$. It was consistent with pineal parenchymal tumor of intermediate differentiation.

The surgical specimen was sent to pathology department. Macroscopic evaluation of the specimen was as follows: Volume of the specimen was 3cc. It consisted of irregular piece of tissues, dirty white and red in color. It were fixed in $4 \%$ formaline solution and embedded in paraffin, then cut into $4 \square \mathrm{m}$ sections. Routine staining was performed using haematoxylin-eosin.

Histopathological examination of operation material revealed a diffuse, highly cellular tumor composed of small, uniform, round cells with mild nuclear atypia. Tumor was moderately differentiated, insignificant 
patterned with relatively monomorphous appearance. Mitotic counts were very low (1 per 10 high-power field). There was no evidence of necrosis or pineocytomatous rosettes. But numerous vessels were seen (Figure 1).

Immunhistochemical examination demonstrated strong and diffuse staining for synaptophysin (Figure 2). There was no expression of GFAP (Figure 3) or chromogranin A (Figure 4) in tumor. Approximately $7 \%$ of the tumor cells revealed positive staining for Ki-67 (Figure 5).

The final diagnosis, according to WHO criteria was PPTID, grade II (7).

\section{DISCUSSION}

The current WHO classification distinguishes between PC, PB and PPTID. PPTID is a tumor with histological features resembling both pineocytoma and pineoblastoma. It was introduced to describe a group of tumors intermediate in malignancy as grade II or III (1).

PPTID constitutes approximately $10 \%$ of all PPTs. An accurate frequency of occurrence is unclear because of the diagnostic difficulties, both clinically and pathologically $(5,2)$. It is difficult and also subjective for the pathologist to make a decision between grade II or III.

Only a limited number of cases about PPTID have been reported in the pathology literature, and histopathological grading of these tumors remains controversial. It has been suggested that a grading system based on mitotic activity and neurofilament protein immunoreactivity can distinguish low- from high-grade PPTID (2). Recently, Jouvet et al (2) proposed a new prognostic grading comprising four grades: Grade I for PC; grade IV for PB and grades II and III for PPTID, with grade II being defined as having fewer than six mitotic figures per $10 \mathrm{HPF}$, positive immunolabelling of neurofilament; and grade III being define as having six or more mitotic figures per HPF or fewer than six mitotic figures but without immunostaining for neurofilament. According to that our case would correspond to a grade II (2).

We present a case of the patient with PPTID in pineal region. Diagnosing PPTID can be difficult and histopathologic findings are not patognomonic. Also there is no case reported about intraoperative consultation of pineal tumors as we know. It can be discussed if it is valuable or not. It is more difficult to grade and diagnose PPTID correctly on frozen section.
As our conclusion, it is preferable to use different nomenclature for different grades of PPTID, similar to classification of astrocytomas. Thus, it may prevent misdiagnoses of grading PPTs. An accurate grading is essential for these rare tumors, because optimal therapeutic management and prognosis depend on histopathological grading.

\section{REFERENCES}

1. Nakazato Y, Jouvet A, Scheithauer BW. Pineal parenchymal tumor of intermediate differentiation. In: Louis DN (ed) World Health Organization Classification of Tumours of the Central Nervous System. 4th edn. WHO, 2007; 7:124-5.

2. Jouvet A, Saint-Pierre G, Fauchon $F$ et al. Pineal parenchymal tumors: a correlation of histological features with prognosis in 66 cases. Brain Pathol 2000; 10:49-60.

3. Nakazato $Y$, Jouvet A, Scheithauer BW. Pineocytoma. In: World Health Organization Classification of Tumours of the Central Nervous System, Chapter 7. DN Louis, $H$ Ohgaki, ODWiestler, WK Cavenee (eds). IARC: Lyon. 2007: 122-3.

4. Mena $H$, Nakazato $Y$, Jouvet A, Scheithauer BW. Pineoblastoma. Pineocytoma. Pineal parenchymal tumours of intermediate differentiation. In: Kleihues $P$, Cavenee WK (eds) Tumours of the nervous system. 2nd edn. IARC, Lyon. 2000:116-21.

5. Fauchon $F$, Jouvet $A$, Paquis $P$ et al. Parenchymal pineal tumors: a clinicopathological study of 76 cases. Int $J$ Radiat Oncol Biol Phys 2000; 46: 959-68.

6. Pusztaszeri M, Pica A, Janzer R. Pineal parenchymal tumors of intermediate differentiation in adults: case report and literature review. Neuropathology 2006; 26: 153-7.

7. Schild SE, Scheithauer BW, Schomberg PJ et al. Pineal parenchymal tumors. Clinical, pathologic, and theurapeutic aspects. Cancer 1993; 72: 870-80.

8. Mena $H$, Nakazato $Y$, Jouvet $A$, et al. Pineal parenchymal tumors. In: Kleiheus P, Cavenee WK, editors. The WHO Classification of Tumours of the Central Nervous System. Lyon: IARC Press; 2002: 115-22.

9. Rickert $\mathrm{CH}$, Simon $\mathrm{R}$, Bergmann M, Dockhorn-Dworniczak $B$, Paulus W. Comparative genomic hybridization in pineal parenchymal tumors. Genes Chromosomes Cancer 2001; 30: $99-104$ 